\title{
Food crop supply in sub-Saharan Africa and climate change
}

\author{
Elodie Blanc \\ Joint Program on the Science and Policy of Global Change Massachusetts Institute of Technology, \\ 77 Massachusetts Ave, E19-439L, Cambridge, MA 02139-4307, USA.
}

Accepted 17 July, 2013

\begin{abstract}
This study estimates the impact of climate change on supply for the four most common crops (millet, maize, sorghum and cassava) in sub-Saharan Africa (SSA). The analysis relates crop supply, measured as cropped area, to weather, climate and prices. Crop supply functions are estimated using an error correction model (ECM) built on panel data. Crop supply through 2100 is predicted by combining estimates from the panel data analysis with climate change predictions from 20 general circulation models (GCMs). Results indicate climate change impacts on crop supplies ranging from -20 to $+133 \%$ compared to a scenario of no climate change.
\end{abstract}

Key words: Food crop supply, climate change, error correction model.

\section{INTRODUCTION}

Food crop production is essential in developing countries, especially sub-Saharan Africa (SSA) where agriculture is the main source of food and livelihood (Badiane and Delgado, 1995). However, agriculture is particularly vulnerable to weather in SSA where $97 \%$ of agricultural land is rain fed (Rockström et al., 2004). The impact of climate change on crop supply is therefore a major concern in this region.

Crop supply analyses generally estimate the responsiveness of agricultural production to price incentives. In SSA, where most of the population is rural and depends on domestic food crop production for subsistence, the influence of price changes on production decisions is disputable. The effect of price on African cash crop supply response has been widely considered (Parikh, 1979; Bond, 1983; Hattink et al., 1998; Thiele, 2003; Douya, 2008). The small number of studies focusing on food crops concludes that price changes have a small effect on supply decisions (McKay et al., 1998; Rahji et al., 2008). Other factors, such as weather and climate, may be more important in determining supply in developing countries.

While several studies have assessed the impact of climate change in Africa, most studies focus on crop productivity (Ben Mohamed et al., 2002; Van Duivenbooden et al., 2002; Jones and Thornton, 2003; Thornton et al., 2009; Schlenker and Lobell, 2010). Studies estimating the impact of climate change on crop supply are scarcer and mainly consider impacts at the global level using computable general equilibrium (CGE) models (Adams et al., 1995; Darwin et al., 1995; Adams et al., 1999). Within the relatively small number of regional studies, most supply functions focusing on developing countries are estimated using econometric techniques, but do not consider the impact of climate change (de Vries 1975; Bond, 1983; Mendelsohn et al., 1994; Subervie, 2008). This study fills this gap by quantifying the effects of climate change on crop supply in SSA using an econometric analysis. The supply function can be estimated either at the aggregate level 
(Bond, 1983; McKay et al., 1998; Thiele, 2003) or at the commodity level (Parikh, 1979; Hattink et al., 1998; Douya, 2008; Rahji et al., 2008), while aggregation enables estimation of more general supply responses, it provides rather inelastic short run effects (Binswanger et al., 1987) and does not allow determination of the specific effect of one input on a particular output (Just et al., 1983). As crop supply responses to changes in inputs, and especially weather, may vary considerably from crop to crop, this study estimates separate supply functions for each of the four main cultivated crops in SSA: millet, maize, sorghum and cassava.

\section{Modeling framework}

\section{Functional form}

Agricultural supply functions are generally estimated using either a profit maximization framework or econometric techniques. The profit maximization method is not suitable for this study as the assumption of profit maximization does not necessarily hold for African farmers (Ogbu and Gbetibouo, 1989; Udry, 1999) and input prices are not available for SSA. The Nerlovian model (Nerlove, 1956), which models farmers' supply decisions in terms of price expectations and/or partial area adjustments, has been extensively used to estimate agricultural supply response. However, several problems are associated with estimation of the Nerlovian model. The first issue relates to the partial adjustment representation through the inclusion of lagged output as an explanatory variable. Lagged output is likely to be linked to lagged prices through a demand function relationship. Therefore, estimates of the long-run supply elasticity may be biased (Braulke, 1982).

Moreover, as acknowledged by Nerlove (1979), the partial adjustment model implies that output at period $t$ adjusts in an ad hoc fashion by a fraction of the change required to attain desired output. Also, the assumption that the desired output level is fixed is questionable. The second issue regards the estimation of long-run price responses. When both partial adjustment and adaptive price expectations are included in the model, it is not possible to estimate long-run elasticities unless certain restrictions are applied (Nerlove, 1958). Some issues regarding the estimation of the Nerlovian model have been addressed by modifying the original model (Leaver, 2004) and using panel data (Thiele, 2000).

The supply function can be reformulated as an error correction model (ECM). The ECM is preferable to the Nerlovian model for several reasons: (i) it addresses the problem of spurious regression that can be present when using non stationary time series; (ii) it enables separate estimation of short and long-run elasticities; and (iii) it relaxes the restrictive adaptive assumptions imposed by the dynamic specification of the Nerlovian model and is representative of 'forward-looking behaviour' (Thiele, 2000). ECMs have been preferred to partial adjustment models in many studies of agricultural supply response in SSA, both at the aggregate level (McKay et al., 1998; Muchapondwa, 2009) and the individual crop level (Alemu et al., 2003; Mose et al., 2007; Nkang et al., 2007).

\section{Regression specifications}

A general crop supply function can be specified as:

Ait $=f($ Priceit-1, Weatherit-1, Riskit-1)

Where for each crop i at time t, A represents the area harvested, Price is a vector of price variables, Weather is a vector of weather variables and Risk is a vector of risk factor.

According to Askari and Cummings (1977; p. 260) "planted acreage is generally the best available method of gauging how cultivators translate their price expectations into action." However, these authors also argue that farmers are more interested in adjusting output to price changes than area under cultivation. They assume that farmers can influence output levels by increasing other production factors such as fertilizer, labor and irrigation. However, when considering SSA, where fertilizer and irrigation are scarcely used, these output adjustment possibilities are limited. Additionally, area cultivated is a better indicator of production planning as it is independent of contemporaneous weather events (Coyle, 1993). Therefore, area cultivated is the preferred output measure in this study.

The effect of price on supply responses in Africa is usually estimated by considering agricultural aggregates (Bond, 1983; McKay et al., 1998; Thiele, 2003) or export and cash crops (Parikh, 1979; Hattink et al., 1998; Douya, 2008). The few statistical studies that consider the supply response of food crops to price incentives find small elasticities (McKay et al., 1998; Rahji et al., 2008). These small price effects are plausible in the SSA agricultural sector, which is mainly characterized by subsistence farming (Amissah-Arthur, 2005; NRC, 2008). African subsistence farmers have limited roads and transportation means, which isolate them from markets (NRC, 2008). Isolation and lack of spending possibilities further limits income needs and therefore price incentives. The effect of prices can also be hidden by crop rotation practices where crops are substituted form year-to-year independently of price changes (Bhagat, 1989). Alternatively, crop supply decisions can be influenced by the price of other potentially cultivable crops through a substitution effect. Cash crop prices can also have a complementary effect with food crops.

In Africa, inputs such as fertilizers are accessed mainly by cash crop farmers through commodity supporting 
institutions (e.g. cotton parastatals in Benin (Minot et al., 2000). Cash crop farmers may use part of their inputs to cultivate food crops. However, studies generally find low export crop price elasticities for food production in SSA (Jaeger 1991; McKay et al., 1998). The supply responses to price rises can differ from responses to price reductions. Asymmetric response studies generally demonstrate that farmers adapt their supply more readily to prices increases than to price decreases (Olayemi and Oni, 1972; Ngambeki and Idachaba, 1985). Crop supply is usually also influenced by input prices, but it is not necessarily applicable in SSA, as very little capital and other related inputs are used in traditional crop production (Wolman and Fournier, 1987). Labor, which is the major production factor in agricultural production (IAC, 2004) is composed mainly of family members (Upton, 1987). Input prices are therefore not included in the specification.

Farmers decisions regarding the area allocated to each crop can be influenced by weather expectations and observed climate change. Weather forecasts and their timing are important for farming decisions such as planting and harvesting (Smit and Skinner, 2002). However, their use for subsistence farmers in developing countries is a challenge due to credibility, geographic scale, understanding ability, broadcasting barriers and information range availability constraints (Patt and Gwata, 2002). For instance, based on field surveys of small farmers in semi-arid Kenya, Recha et al. (2008) reveal that the majority of farmers do not trust meteorological forecasts and only a small number make decisions based on climate forecasts. Given the low reliance of farmers on weather forecasts, farmers base their decisions on perceived climate change over previous years. African farmers appear to be good at detecting changes in climate. Based on a large survey of African farmers, Maddison (2006) and Nhemachena and Hassan (2007) revealed that a significant number of farmers correctly perceive changes in climate, especially experienced farmers. To account for the effect of weather on crop area decisions, studies generally consider previous year weather events (Brons et al., 2004) or weather events before planting (Lahiri and Roy, 1985; Alemu et al., 2003). Given the large number of countries considered in this study, and hence diversity in cropping seasons, weather events from previous years are considered to determine planting decisions.

African subsistence farmers are risk adverse (Bond, 1983) and endure remarkably greater risks than other farmers (Collier and Gunning, 1999). In SSA, weather and market dependency are the main risk factors considered in crop selection decisions (Bond, 1983). Aversion for weather risks can induce a preference for drought resistant crops rather than high-yield crops (Bond, 1983) or diversification of activities across food and cash crops, livestock and wage employment (Collier and Gunning, 1999). Some empirical crop supply analyses use the standard deviation of rainfall to represent weather risk (Savadatti, 2007). The risk of market failure to provide supplies and food discourages diversification of production in Africa (Bond, 1983), and price instability also affects investment decisions (Boussard et al., 2005). The effect of market risk on crop supply is usually investigated using the standard deviation of prices and has a negative effect on supply (Sangwan, 1985; Savadatti, 2007; Huq and Arshad, 2010).

Other constraints such as inadequate transportation infrastructure, communication channels, market structure and financial and agricultural services, limit access to supplies and services required by African farmers (Bond, 1983; Demery and Addison, 1987). These factors are not included in the analysis due to data limitations. Population density, which influences specialization and unit infrastructure costs (Boserup, 1965), is not considered as annual population data are obtained by interpolation from lower frequency data. Therefore, interannual variations cannot be accurately represented.

To estimate the supply function, two alternative specifications are considered. The first, called the LAG model, relates area cultivated to prices and weather effects from the previous year, as is common in the literature. The second, called the MAVG model, assumes farmers have a long-term memory and relates area cultivated to price and weather variables from multiple years. The LAG model is specified as:

InAit = $f($ InCPit-1, CPincit-1, InCCPit-1, XPIt-1, Tit-1, Pit-1)

This specification includes the crop producer price, CP, from the previous year to avoid endogeneity issues. Price asymmetry is investigated by including a dummy variable, CPinc, equal to one when crop prices increase and zero otherwise. Additionally, the first lag of price of the main competing crop, CCP, is included to represent substitution effects between crops. An export crop price index, XPI, is included in the analysis to account for either complementarily or substitutability among the crop considered and export crops. The impact of weather is considered using precipitation and temperature variables, which are observable by farmers. Other weather variables such as carbon dioxide concentration and evapotranspiration also affect crop productivity (Cure and Acock, 1986; Maunder, 1992; Pandey et al., 2000; Abbas et al., 2005). However, these variables are excluded from this analysis as it is unlikely that farmers can perceive or measure changes in such factors and therefore base production decisions on these variables. Cumulative precipitation, $\mathrm{P}$, and average temperature, $\mathrm{T}$, variables are considered over a 12-month period. Given the wide range of cropping seasons within and across countries, it is not possible to include weather during pre-planting periods for each crop. Also, as area data are only available annually and at the country level, it is not possible to determine area allocation per growing season for countries having two growing seasons. Therefore, precipitation and weather are considered using annual 
averages over the previous year. The MAVG model is specified as:

$\ln A$ it $=f($ it, it , it, it, it, it $)$

In this specification, only the average of export crop prices over the previous five years is included to capture price effects. A period of five years is selected as it produces the highest coefficient of correlation between area cultivated and price variables. The model does not include own-crop price and competing crop price, as data is only available from 1966 and a 5 year average would greatly reduce the sample size. Climate is considered as a weather average over the previous 10 years, which produces the highest coefficient of correlation between areas cultivated and weather variables. Risks are accounted for by including standard deviations of prices, during the previous 5 years, and weather variables and during the previous 10 years.

In both LAG and MAVG specifications, area and price series are log transformed to obtain price elasticities. However, climatic variables are kept in levels to allow the interpretation of the influence of, say, an additional degree Celsius, more meaningful. The estimation procedure follows a general-to-specific strategy. Specifically, in the LAG model, crop price, price asymmetry and competing crop prices are excluded if they are insignificant from the full specification in order to obtain a larger sample, as all other variables are available over a longer time period (from 1961). In the MAVG model, risk and extreme event variables are excluded in the final specification if they are not significant.

\section{Data}

Area harvested for each crop at the country level are sourced from FAOSTAT (2007). Using area harvested to represent supply is not ideal as area harvested excludes area sown or planted that is not harvested due to, for example, natural calamities or economic considerations (FAO, 2010). However, planted area data are not available over long time periods and large regions. To account for differences between planted and cultivated area, drought and flood dummies for the current year are included as explanatory variables to represent extreme climatic events. Drought and flood variables are constructed following Blanc (2012). War dummies are included to account for area not harvested due to extreme political conditions. War data are obtained from the Uppsala Conflict Data Program/International Peace Research Institute (UCDP/PRIO) armed conflict dataset (Gleditsch et al., 2002).

Price data are sourced from FAOSTAT (2007) at the national level from 1966 to 2006. Competing crop prices series are created using the price series of the crop with the largest area harvested on average over the study period (1961 to 2002) in each country. If the crop with the largest area is the crop considered, then the competing crop is the crop with the second largest area harvested.

Crop prices are converted from local currency into a common unit (international dollars) using Summers and Heston's PPP real exchange rates extracted from the Penn World Tables version 6.2 (Heston et al., 2006). Export crops prices are represented by the agricultural export unit value index provided by FAOSTAT (2007) from 1961 to 2002.

Weather data are obtained from the CRU TS 2.1 dataset (Mitchell and Jones, 2005). Data at the $0.5 \times 0.5$ degree resolution are available over the period 1901 to 2002. Satellite-derived land cover data from Leff et al. (2004) are used to restrict weather data to crop production areas. Crop growing location data representative of the 1990 s are also available at the $0.5 \times$ 0.5 degree resolution. Weather data for each crop are weighted by area harvested for each crop in each grid cell, relative to the total area harvested.

Data summary statistics for each crop are reported in Table 1. Cultivated area increased for all crops and the most widely harvested crop is sorghum. Real crop prices are generally increasing over the study period. Export price index series increase until the 1980s, stagnate in the mid-1980s and a slowly decrease thereafter. Over the period 1961 to 2002, temperatures generally increased and precipitation decreased slightly.

\section{METHODOLOGY}

A panel analysis is preferred in this study to increase sample size, and because panel methods allow the user to control for time invariant unobservable factors that might affect the estimated coefficients. However, panel estimations assume that the set of determining factors and the impact of each factor on agricultural outcomes is the same for all countries, which is questionable when considering a large number of countries. Most SSA countries are low income countries (Diao et al., 2006) and while African countries generally share similar economic characteristics (Collier, 1993), various agricultural systems coexist (Dixon et al., 2001). Based on growth potential for these different farming systems and their prevalence in each country, Diao et al. (2006) distinguishes African countries with less favorable agricultural conditions (LFAC) from countries with more favorable agricultural conditions (MFAC). LFAC countries include Botswana, Burundi, Chad, Gabon, Madagascar, Mali, Mauritania, Namibia, Niger and Rwanda.

Parameter heterogeneity is investigated by interacting explanatory variables with LFAC dummies, where the LFAC dummy equals one for LFAC countries and zero for MFAC countries. Considering agricultural conditions also allows the analysis to account for the effect of different omitted parameters. For instance, LFAC countries have systems with low growth potential that can be characterized by small farm size, poor infrastructure, lack of resources and/or appropriate technologies, or slow market place development, which are not modeled. Alternatively, countries with more favorable conditions are composed of irrigated or intercropping systems that have a good agricultural growth potential. As a result, the effect of weather will be more important in LFAC countries and weather-LFAC interactions allow the regressions analyses to capture such differences.

Prior to estimating the production function, it is necessary to 
Table 1. Summary statistics.

\begin{tabular}{|c|c|c|c|c|c|c|c|}
\hline Variable & Name & Crop & Obs & Mean & Std dev & Min & Max \\
\hline \multirow{4}{*}{ Area } & \multirow{4}{*}{ A } & Cassava & 1428 & 233,070 & 456,849 & 0 & $3,446,000$ \\
\hline & & Maize & 1554 & 387,204 & 608,123 & 936 & $5,472,000$ \\
\hline & & Millet & 1302 & 457,671 & 980,445 & 0 & $5,814,000$ \\
\hline & & Sorghum & 1386 & 467,515 & $1,092,950$ & 375 & $7,809,000$ \\
\hline \multirow{4}{*}{ Temperature } & \multirow{4}{*}{$\mathrm{T}$} & Cassava & 1428 & 24.7 & 2.5 & 18.1 & 29.2 \\
\hline & & Maize & 1554 & 24.3 & 3.5 & 10.7 & 29.4 \\
\hline & & Millet & 1302 & 24.9 & 2.9 & 18.6 & 29.5 \\
\hline & & Sorghum & 1386 & 24.5 & 3.7 & 10.6 & 29.5 \\
\hline \multirow{4}{*}{ Precipitation } & \multirow{4}{*}{$\mathrm{P}$} & Cassava & 1428 & 1260 & 541 & 218 & 3269 \\
\hline & & Maize & 1554 & 1061 & 482 & 79 & 2822 \\
\hline & & Millet & 1302 & 992 & 457 & 88 & 2960 \\
\hline & & Sorghum & 1386 & 987 & 474 & 60 & 2961 \\
\hline \multirow{4}{*}{ Crop price } & \multirow{4}{*}{$\mathrm{CP}$} & Cassava & 555 & 290 & 311 & 31 & 2061 \\
\hline & & Maize & 555 & 413 & 283 & 39 & 2055 \\
\hline & & Millet & 444 & 507 & 357 & 47 & 2042 \\
\hline & & Sorghum & 481 & 436 & 343 & 41 & 2408 \\
\hline \multirow{4}{*}{ Competing crop price } & \multirow{4}{*}{ CCP } & Cassava & 555 & 578 & 599 & 39 & 4122 \\
\hline & & Maize & 555 & 650 & 633 & 32 & 4122 \\
\hline & & Millet & 444 & 628 & 651 & 32 & 4122 \\
\hline & & Sorghum & 481 & 590 & 637 & 32 & 4122 \\
\hline Export price index & XPI & All crops & 1470 & 101 & 70 & 8 & 483 \\
\hline
\end{tabular}

determine whether or not the data are stationary (that is, the mean and variance remain constant over time) to determine whether 'standard' regression techniques can be used or if a cointegration approach is required to avoid finding a spurious relationship among variables. Stationarity is investigated using the Elliott-RothenbergStock (ERS) test (Elliott et al., 1996). A constant and a time trend are included in the test as the data generating process is not known a priori. Initially, the test is performed on variables in first difference to ensure that the series are not integrated of an order higher than one, and thereafter performed on the level of the series. All variables that are not integrated of an order greater than one are tested for cointegration. Time series are said to be cointegrated if variables share the same stochastic trend so that a linear combination of them is stationary. In this case, a long-run relationship exists and the relationship is not spurious. To determine if a relationship exists between crop supply and postulated determinants, a formal test of cointegration is applied. A cointegration test developed by Westerlund (2007) is preferred as it allows for dependence within cross-sectional units.

The choice of estimator depends on the model to be estimated and the properties of the data. In this analysis, diagnostic tests are used to test for individual fixed effects (that is, the presence of permanent differences between countries), time effects (that is, the presence of effects that vary over time but not across countries), cross-sectional and serial correlation (spatially and temporally correlated errors can lead to underestimate standard errors), and homoskedasticity (standard errors are no longer valid when the assumption of homoscedasticity, that is, the variance of the error term is constant, is not satisfied). An F-tests is used to test for the significance of individual and time effects. The Breusch-Pagan (described in Greene, 2000; p. 601) and Pesaran (2004) tests are used to test for cross-sectional independence. Arellano and Bond (1991) test is applied to test for the absence of autocorrelation. Heteroskedasticity is tested using the panel heteroskedasticity test described by Greene (2000).

The estimation procedure is determined by the results of the different tests presented above. Depending on the stationarity and cointegration tests results, the specification is estimated in levels, first differences or using an ECM. The diagnostic tests outlined above are then implemented to determine the proper estimator for each regression.

\section{REGRESSION RESULTS AND DISCUSSION}

Results at the completion of the general-to-specific estimation procedure (final regression results) for the LAG model and the MAVG models are presented. A summary of the specification for each model is presented in Table 3. As mentioned earlier, we follow a general-tospecific estimation which consists of excluding insignificant control variables from the full specification (that is, crop price, price asymmetry and competing crop prices in the LAG and model and risk and extreme event variables in the MAVG model).

ERS unit root tests indicate that most series are 
Table 2. Diagnostic tests statistics.

\begin{tabular}{|c|c|c|c|c|c|}
\hline $\mathrm{H}_{0}$ & Model & Cassava & Maize & Millet & Sorghum \\
\hline \multirow{2}{*}{ No cointegration } & LAG & -11.405 & $-17.716^{\star \star *}$ & -12.983 & $-16.822^{\star \star}$ \\
\hline & MAVG & $-22.372^{* * *}$ & $-20.866^{* * *}$ & $-18.46^{* * *}$ & $-20.562^{* * *}$ \\
\hline \multirow{2}{*}{ Cross-sectional independence } & LAG & -0.082 & 0.387 & $-1.794^{\star}$ & $-2.153^{\star *}$ \\
\hline & MAVG & $2.919^{* * *}$ & 0.830 & $-2.596^{\star \star \star}$ & $-1.839^{*}$ \\
\hline \multirow{2}{*}{ No autocorrelation of order 1} & LAG & -1.052 & $-3.340^{* * *}$ & $-2.845^{\star * *}$ & $-3.299^{* * *}$ \\
\hline & MAVG & -1.07 & $-3.340^{\star * *}$ & $-1.799^{\star}$ & $-3.299^{* * *}$ \\
\hline \multirow{2}{*}{ Homoskedasticity } & LAG & $16,678^{\star * \star}$ & $8,093^{\star * *}$ & $3,963^{\star * *}$ & $1081^{* \star *}$ \\
\hline & MAVG & $8,154^{\star * *}$ & $5,966^{\star * *}$ & $1,121^{* * *}$ & $1,105^{\star * *}$ \\
\hline
\end{tabular}

Note: ${ }^{* *},{ }^{* *}$ and ${ }^{*}$ denote significance at the 1,5 and $10 \%$ level, respectively.

stationary in first difference [that is, I(1)]. The models should be estimated using first differences except when a long-run relationship between the variables exists. Westerlund's (2007) panel cointegration test is therefore performed for each regional regression. Based on Westerlund's (2007) panel cointegration tests statistics reported in Table 2, ECMs are estimated for maize and sorghum in the LAG model (cassava and millet are estimated in first difference) and for all crops in the MAVG model. Guided by results from diagnostic tests, Driscoll and Kraay (1998) standard errors, which are robust to general forms of cross-sectional dependence, autocorrelation and heteroskedasticity, are estimated.

\section{LAG model}

Final regression results for the cassava LAG supply function are presented in Table 4. Coefficients for the error correction term, ECTt-1, are significant, supporting the cointegration test results for maize and sorghum presented in Table 2 . The largest ECTt 1 coefficient is observed for maize $(-0.26)$ and indicates that about a quarter of the disequilibrium is corrected each year.

The coefficient of own-crop prices and competing crop prices do not significantly influence cultivation decisions and are not reported in Table 4. This finding is consistent with the fact that the food crops considered are mainly grown for domestic consumption. The export crops price index (XPI) has a significant and positive effect on maize area, indicating a complementarity effect between maize and export crops. As noted earlier, inputs such as fertilizers are accessed mainly by cash crops growers in SSA. Therefore, an increase in export crop prices inducing an increase in cash crop supply entails, in parallel, an increase in food crop supply as farmers use part of their inputs to cultivate food crops. In LFAC countries, export crop price has a negative effect on sorghum acreage. This result can indicate that as the export crops price increases, farmers either replace sorghum with export crops, or substitute sorghum for another higher yielding but more fertilizer-demanding food crop.

Previous year temperature $(T)$ has a significant positive impact on planting decisions for maize, millet and sorghum. For instance, a $1^{\circ} \mathrm{C}$ increase in temperature in the previous year causes a 7.95, 7.44 and $4.21 \%$ increase in maize, millet and sorghum area, respectively. As temperature increases have a negative effect on yields for these crops in SSA (Yamoah et al., 1998; Odjugo, 2008), the positive impact of temperature on area could be explained by a yield loss compensation mechanism to maintain production levels when temperature increases. For cassava, however, an increase in temperature induces a decrease in cassava area cultivated in LFAC countries. This result seems contradictory to what is observed for the three other crops. However, cassava has a high optimum temperature $\left(35^{\circ} \mathrm{C}\right)$ (Hillocks et al., 2001) and increased temperature can have a positive effect on cassava yields (Weite et al., 1998). Therefore, as desired production levels would be reached more easily following an increase in temperature, area planted in LFAC countries would decrease. The temperature coefficient for MFAC countries is positive and indicates that MFAC countries farmers would increase cassava production when temperature increases. These results are consistent with the observation that LFAC farmers have limited access to markets to sell excess production, whereas MFAC farmers have more buying and selling opportunities (Diao et al., 2006). However, the impact of temperature in LFAC countries is insignificant so it is not possible to draw any firm conclusions for these countries.

Precipitation $(P)$ has similar consequences on cassava supply decisions. Previous year precipitation has a significant and positive effect in MFAC countries, and a significant and negative in LFAC countries. For example, a $100 \mathrm{~mm}$ increase in precipitation causes a $0.5 \%$ acreage 
Table 3. Summary of regression specifications.

\begin{tabular}{|c|c|c|c|}
\hline \multicolumn{2}{|r|}{ LAG model } & \multicolumn{2}{|r|}{ MAVG model } \\
\hline Variable & Description & Variable & Description \\
\hline$\Delta \mathrm{XPI}_{\mathrm{t}-1}$ & Change in previous year export price index & $\Delta X \bar{P} \mathbf{I}$ & Change in export price index averaged over the past five years \\
\hline$\Delta \mathrm{T}_{\mathrm{t}-1}$ & Change in previous year temperature & $\Delta \overline{\mathbf{T}}$ & Change in temperature averaged over the past ten years \\
\hline \multirow[t]{2}{*}{$\Delta \mathrm{P}_{\mathrm{t}-1}$} & Change in previous year precipitation & $\Delta \overline{\mathbf{P}}$ & Change in precipitation averaged over the past ten years \\
\hline & & $\Delta \tilde{\mathbf{P}}$ & Change in standard deviation of precipitation over the past ten years \\
\hline$\Delta$ Drought $_{\mathrm{t}-1}$ & Change in previous year drought & $\Delta$ Drought & Change in drought averaged over the past ten years \\
\hline$\Delta(\mathrm{XPI} \times \mathrm{LFAC})_{\mathrm{t}-1}$ & Change in previous year export price index for LFAC countries & $\Delta(\mathbf{X} \overline{\mathbf{P}} \mathbf{I} \times \mathbf{L F A C})$ & Change in export price index averaged over the past five years for LFAC countries \\
\hline$\Delta(T \times L F A C)_{t-1}$ & Change in previous year temperature for LFAC countries & $\Delta(\overline{\mathbf{T}} \times \mathbf{L F A C})$ & Change in temperature averaged over the past ten years for LFAC countries \\
\hline$\Delta(\mathrm{P} \times \mathrm{LFAC})_{\mathrm{t}-1}$ & Change in previous year precipitation for LFAC countries & $\Delta(\overline{\mathbf{P}} \times \mathbf{L F A C})$ & Change in precipitation averaged over the past ten years for LFAC countries \\
\hline$\Delta(\text { Drought } \times \text { LFAC })_{t-1}$ & Change in previous year drought for LFAC countries & $\Delta(\tilde{\mathbf{P}} \times \mathbf{L F A C})$ & Change in standard deviation of precipitation over the past ten years for LFAC countries \\
\hline $\mathrm{ECT}_{\mathrm{t}-1}$ & Previous year Error Correction Term & $\mathrm{ECT}_{\mathrm{t}-1}$ & Previous year Error Correction Term \\
\hline
\end{tabular}

acreage increase in MFAC countries (that is, $5.05 e-05 \times 100)$ and a $0.6 \%$ acreage decrease in LFAC countries (that is, 5.05e-05 $\times 100$ $0.000113 \times 100)$. Precipitation generally has a positive impact on crop yields (Larsson, 1996; Zaal et al., 2004; Fermont et al., 2009). When precipitation increases, farmers from LFAC countries reduce area cultivated as production targets are attained more easily under better rainfall conditions and opportunities to sell excess production are limited Alternatively, farmers from MFAC countries increase cassava area when rainfall increases as they can more easily sell excess production.

When considering rainfall and temperature decreases, the results imply that farmers in LFAC countries increase cassava area to compensate for a yield decrease, and farmers in MFAC countries switch to more suited crops or other activities, although this is not explicitly modeled in the analysis. Among the control variables included in initial specifications to account for differences between planted and cultivated area, only drought is significant for maize and sorghum. The drought coefficients have the expected sign in these regressions.

\section{MAVG model}

Regression results for the MAVG supply function are reported in Table 5. Based on cointegration tests results, ECMs are estimated for all crops ECTt- 1 coefficients obtained are all significant and support the existence of an adjustment toward a long-run equilibrium. The fastest adjustment is observed for maize where the ECTt- 1 coefficient is equal to 0.262 .

The average export crop price index $(X \bar{P} I)$ is insignificant in all regressions, except cassava, where it has a significant negative effect on acreage response in LFAC countries. This result indicates a long-term substitution effect between export crops and cassava in LFAC countries. Export crop price risks are not significant and are removed from the final regressions. Average temperature $(\bar{T})$ has a significant positive impact on sorghum acreage only. For this crop, a $1^{\circ} \mathrm{C}$ increase in ten-year average temperature causes a $46.6 \%$ increase in area dedicated to sorghum. As for the LAG model, the MAVG model indicates that in response to an increase in temperature, farmers increase sorghum area in order to compensate for yield losses. However, the temperature coefficient estimated for the MAVG model is slightly larger than the temperature effect estimated with the LAG model for sorghum. This result indicates that a persistent change in temperature is more influential on area planted than short term temperature changes.

Average precipitation over the previous 10 years $(\bar{P})$ is a significant determinant of maize and sorghum planting decisions. For these crops, a $100 \mathrm{~mm}$ increase in precipitation over the last decade causes a $5.86 \%$ decrease in maize area and a $6.01 \%$ decrease in sorghum area. These results indicate that, as climatic conditions improve, farmers switch to better yielding but more water demanding crops, or (possibly only in LFAC 
Table 4. LAG model regressions: dependent variable $\Delta \mathrm{InA}$.

\begin{tabular}{|c|c|c|c|c|}
\hline Parameter & Cassava & Maize & Millet & Sorghum \\
\hline$\Delta \mathrm{XPI}_{\mathrm{t}-1}$ & $\begin{array}{l}-0.000267 \\
(0.000343)\end{array}$ & $\begin{array}{l}0.000402^{\star *} \\
(0.000150)\end{array}$ & $\begin{array}{c}1.53 \mathrm{e}-06 \\
(0.000170)\end{array}$ & $\begin{array}{c}0.000213 \\
(0.000215)\end{array}$ \\
\hline$\Delta \mathrm{T}_{\mathrm{t}-1}$ & $\begin{array}{c}0.0290 \\
(0.0228)\end{array}$ & $\begin{array}{l}0.0795^{\star *} \\
(0.0323)\end{array}$ & $\begin{array}{l}0.0744^{*} \\
(0.0380)\end{array}$ & $\begin{array}{l}0.0421^{*} \\
(0.0208)\end{array}$ \\
\hline$\Delta \mathrm{P}_{\mathrm{t}-1}$ & $\begin{array}{l}5.05 e-05^{* *} \\
(2.03 e-05)\end{array}$ & $\begin{array}{l}-1.62 \mathrm{e}-05 \\
(2.92 \mathrm{e}-05)\end{array}$ & $\begin{array}{l}-9.85 e-06 \\
(3.18 e-05)\end{array}$ & $\begin{array}{c}-1.25 \mathrm{e}-06 \\
(3.55 \mathrm{e}-05)\end{array}$ \\
\hline$\Delta$ Drought $_{\mathrm{t}-1}$ & & $\begin{array}{c}-0.0861^{* * *} \\
(-0.0234)\end{array}$ & & $\begin{array}{l}-0.0540^{*} \\
(-0.0276)\end{array}$ \\
\hline$\Delta(\mathrm{XPI} \times \mathrm{LFAC})_{\mathrm{t}-1}$ & $\begin{array}{c}0.000584 \\
(0.000409)\end{array}$ & & & $\begin{array}{c}-0.00100^{* *} \\
(0.000422)\end{array}$ \\
\hline$\Delta(\mathrm{T} \times \mathrm{LFAC})_{\mathrm{t}-1}$ & $\begin{array}{l}-0.0524^{*} \\
(0.0270)\end{array}$ & & & $\begin{array}{l}-0.0173 \\
(0.0249)\end{array}$ \\
\hline$\Delta(\mathrm{P} \times \mathrm{LFAC})_{\mathrm{t}-1}$ & $\begin{array}{c}-0.000113^{* *} \\
(5.45 \mathrm{e}-05)\end{array}$ & & & $\begin{array}{c}-8.38 \mathrm{e}-05 \\
(0.000136)\end{array}$ \\
\hline$\Delta(\text { Drought } \times \text { LFAC })_{t-1}$ & & & & $\begin{array}{c}-0.0245 \\
(-0.0508)\end{array}$ \\
\hline $\mathrm{ECT}_{\mathrm{t}-1}$ & & $\begin{array}{c}-0.258^{\star \star \star} \\
(0.0293)\end{array}$ & & $\begin{array}{c}-0.211^{\star * *} \\
(0.0280)\end{array}$ \\
\hline Constant & $\begin{array}{c}0.0123^{*} \\
(0.00611)\end{array}$ & $\begin{array}{c}0.0913^{* * *} \\
(0.0251)\end{array}$ & $\begin{array}{l}0.0734^{\star *} \\
(0.0292)\end{array}$ & $\begin{array}{c}0.0139 \\
(0.0150)\end{array}$ \\
\hline Observations & 1,178 & 1,400 & 1,184 & 1,224 \\
\hline Number of groups & 30 & 35 & 30 & 31 \\
\hline $\mathrm{R}^{2}$ & 0.006 & 0.187 & 0.058 & 0.175 \\
\hline $\mathrm{F}$ & $4.195^{\star \star \star}$ & $195.6^{\star \star \star}$ & $21.23^{\star * *}$ & $2,099^{* * *}$ \\
\hline Time dummies & No & Yes & Yes & Yes \\
\hline Fixed effect & No & Yes & No & Yes \\
\hline ECM & No & Yes & No & Yes \\
\hline
\end{tabular}

Standard errors in parentheses; ${ }^{* * *},{ }^{* *}$ and * denote significance at the 1, 5 and $10 \%$ level, respectively; Results for control variables are not presented in this table.

countries) that farmers can achieve production targets more easily and thus reduce area planted. A decrease in long-term rainfall would lead to an increase in planted area to compensate for yield losses.

An increase in precipitation risk $(\tilde{P})$ has a negative effect on cassava planting in MFAC countries but a positive effect in LFAC countries. For example, a one standard deviation increase in precipitation variability in the previous 10 years leads to a $0.08 \%$ decrease in cassava area in MFAC countries and a $0.05 \%$ increase in
LFAC countries. This result could be explained by higher risk aversion of farmers where agricultural conditions are less favorable (in LFAC countries). In these countries, farmers will prefer cassava, which is drought resistant and better able to cope with precipitation changes than other crops. Also, farmers could increase area cultivated to ensure enough production as uncertainty in rainfall increases. In MFAC countries, however, farmers may decrease cassava cultivation as rainfall variability increases because they have alternative subsistence 
Table 5. MAVG model regressions: dependent variable $\Delta \ln A$.

\begin{tabular}{|c|c|c|c|c|}
\hline Parameter & Cassava & Maize & Millet & Sorghum \\
\hline$\Delta \mathbf{X} \overline{\mathbf{P}} \mathbf{I}$ & $\begin{array}{l}-0.000686 \\
(0.000759)\end{array}$ & $\begin{array}{l}-.0007856 \\
(0.000627)\end{array}$ & $\begin{array}{c}0.000186 \\
(0.000561)\end{array}$ & $\begin{array}{c}0.000101 \\
(0.000834)\end{array}$ \\
\hline$\Delta \overline{\mathbf{T}}$ & $\begin{array}{c}-0.00753 \\
(0.191)\end{array}$ & $\begin{array}{r}-0.0430 \\
(0.185)\end{array}$ & $\begin{array}{c}0.375 \\
(0.252)\end{array}$ & $\begin{array}{l}0.466^{* *} \\
(0.197)\end{array}$ \\
\hline$\Delta \overline{\mathbf{P}}$ & $\begin{array}{c}-9.89 \mathrm{e}-06 \\
(0.000212)\end{array}$ & $\begin{array}{c}-0.000586^{\star *} \\
(0.000222)\end{array}$ & $\begin{array}{c}-0.000173 \\
(0.000312)\end{array}$ & $\begin{array}{c}-0.000601^{\star *} \\
(0.000263)\end{array}$ \\
\hline$\Delta \tilde{\mathbf{P}}$ & $\begin{array}{c}-0.000799^{* * \star} \\
(0.000242)\end{array}$ & & & \\
\hline$\Delta$ Drought & & $\begin{array}{c}-0.0606^{\star * \star} \\
-0.0231\end{array}$ & & $\begin{array}{l}-0.0642^{* *} \\
-0.0253\end{array}$ \\
\hline$\Delta(\mathbf{X} \overline{\mathbf{P}} \mathbf{I} \times \mathbf{L F A C})$ & $\begin{array}{l}0.00315^{\star \star \star} \\
(0.000990)\end{array}$ & & & \\
\hline$\Delta(\overline{\mathbf{T}} \times \mathbf{L F A C})$ & $\begin{array}{l}-0.0929 \\
(0.289)\end{array}$ & & & \\
\hline$\Delta(\overline{\mathbf{P}} \times \mathbf{L F A C})$ & $\begin{array}{c}0.000213 \\
(0.000406)\end{array}$ & & & \\
\hline$\Delta(\tilde{\mathbf{P}} \times \mathbf{L F A C})$ & $\begin{array}{c}0.00139^{*} \\
(0.000724)\end{array}$ & & & \\
\hline $\mathrm{ECT}_{\mathrm{t}-1}$ & $\begin{array}{l}-0.115^{\star \star \star} \\
(0.0394)\end{array}$ & $\begin{array}{l}-0.262^{* \star *} \\
(0.0333)\end{array}$ & $\begin{array}{l}-0.208^{\star \star \star} \\
(0.0549)\end{array}$ & $\begin{array}{l}-0.235^{\star \star \star} \\
(0.0270)\end{array}$ \\
\hline Constant & $\begin{array}{l}0.0714^{\star \star \star} \\
(0.00835)\end{array}$ & $\begin{array}{c}0.0943^{\star * *} \\
(0.0116)\end{array}$ & $\begin{array}{c}0.0973^{\star * *} \\
(0.0104)\end{array}$ & $\begin{array}{l}0.143^{\star \star \star} \\
(0.0105)\end{array}$ \\
\hline Observations & 1,062 & 1,260 & 1,068 & 1,104 \\
\hline Number of groups & 30 & 35 & 30 & 31 \\
\hline $\mathrm{R}^{2}$ & 0.109 & 0.182 & 0.147 & 0.181 \\
\hline $\mathrm{F}$ & $21,357^{\star * *}$ & $105^{\star \star *}$ & $2,603^{* * *}$ & $4,256^{\star \star \star}$ \\
\hline Time dummies & Yes & Yes & Yes & Yes \\
\hline Fixed effects & Yes & Yes & Yes & Yes \\
\hline ECM & Yes & Yes & Yes & Yes \\
\hline
\end{tabular}

Notes: standard errors in parentheses; ${ }^{* * *},{ }^{* *}$ and ${ }^{*}$ denote significance at the 1,5 and $10 \%$ level, respectively; Results for control variables are not presented in this table.

means, such as waged employment. As for the LAG model, the drought variable is only significant in the maize and sorghum regressions. Again, the drought coefficients have the expected signs.

\section{Climate change impact predictions}

\section{Climate change scenarios and data}

Climate change predictions from five general circulation models (GCMs) are used in this study: CSIRO2 (Gordon and O'Farrell, 1997), HadCM3 (Gordon et al., 2000), CGCM2 (Flato and Boer, 2001), ECHAM4 (Roeckner et al., 1996) and PCM (Washington et al., 2000). For each model, four alternative future greenhouse gases (GHG) emissions scenarios (A1FI, A2, B1 and B2) proposed by the Intergovernmental Panel on Climate Change (IPCC, 2000) in their Special Report on Emissions Scenarios (SRES) are considered. These emission scenarios are used as inputs into the GCMs detailed above and 
Table 6. RMSEs.

\begin{tabular}{lcccc}
\hline \multirow{2}{*}{ Crop } & \multicolumn{2}{c}{ Individual models } & \multicolumn{2}{c}{ Combined models } \\
\cline { 2 - 5 } & LAG & AVG & Equal weights & Bates and Granger'sweights \\
\hline Cassava & 0.18921 & 0.20109 & 0.18224 & 0.18227 \\
Maize & 0.28561 & 0.27474 & 0.23086 & 0.23089 \\
Millet & 0.24975 & 0.26477 & 0.25333 & 0.25334 \\
Sorghum & 0.25298 & 0.28617 & 0.24603 & 0.24600 \\
\hline
\end{tabular}

postulate different economic, demographic and technologic futures. The combination of the five GCMs and the four scenarios produces 20 plausible futures, each with an equal likelihood of occurrence (Mitchell, 2007). The 20 permutations represent $93 \%$ of possible future changes in climate estimated by the Third Assessment Report of the IPCC (IPCC, 2001).

Data for the four climate scenarios under the five AOGCMs are extracted from the TYN SC 2.0 dataset (Mitchell et al., 2003) and are available at the global level at the $0.5 \times 0.5$ degree resolution. Weather variables under the 20 AOGCMs and scenarios permutations are constructed following the same procedure used in the regression analysis. Over the 21 st century, temperature is predicted to increase under all scenarios. The smallest temperature increases by the late-2000s (2070 to 2099) compared to the late 1900s (1970 to 1999) are predicted under the PCM-B1 scenario $\left(+1^{\circ} \mathrm{C}\right)$, and the largest increases under the HadCM3-A1FI and ECHAM4-A1FI scenarios $\left(+4.7\right.$ to $+4.9^{\circ} \mathrm{C}$, respectively). There is greater divergence in precipitation predictions. By the late-2000s, precipitation changes are predicted to range from $-75 \mathrm{~mm}$ under the CGCM2-A1FI scenario to $+120 \mathrm{~mm}$ under the ECHAM4-A1FI scenario compared to the late-1900s.

\section{Climate change impacts}

Climate change impacts on area cultivated are predicted using both supply models estimated. As both models bring out different information regarding farmers' planting decisions, combining predictions from the two models expands the information set and improves predictions (Timmermann, 2006). Two weighting procedures are considered when combining models: (i) equal weight for each model and (ii) Bates and Granger's (1969) weights based on out-of-sample forecast variances. The predictive power of each model and the combination of both models are assessed using the root mean squared error (RMSE) computed using the leave-one-out crossvalidation method (Michaelsen, 1987). RMSEs for individual and combined models under alternative weights are presented in Table 6 . The calculations show that the predictive power of each model is improved when combining the models, and the smallest RMSEs are obtained using equal weights. Therefore, predictions are calculated using both models weighted equally.

Predictions are calculated using all coefficients used to fit the models. The EC term is dynamically estimated one period ahead by replacing the observed values of crop areas by the estimated values in an iterative fashion. Given the econometric-based nature of the analysis, it is not possible to account for future prices change in this study. When making predictions, prices are held at their 2002 values. To prevent area predictions from exceeding total arable land, total area for the four crops is limited to the amount of potential arable land in each country. Estimates of potential arable land by FAO Terrastat (2007) are used. This constraint binds for nine countries. The caveat is that, all potential arable land in these countries is allocated to the four crops. However, because of inter-cropping and cultivation on nonconventional land, it is plausible, to a certain extent, that the total area planted of all crops in one country may exceed the total surface of arable land in one country. Another caveat associated with this approach is that FAO do not provide future arable land estimates, which could be altered by climate change.

To simplify presentation of the results, predictions obtained using all AOGCMs are averaged over three 30year periods: late-1900s (1970 to 1999), which represent the base period, and mid-2000s (2040 to 2059) and late2000s (2070 to 2099) which represent prediction periods. Area cultivated is expected to increase for all crops in the 21 st century compared to the late-1900s. However, these changes are mainly driven by the stochastic trend embodied in the constant. It is questionable that this trend observed in the late-1900s, will continue unabated during the 21st century. The most relevant results for determining the impact of climate change are given by comparing predictions with climate change to predictions without climate change (reference scenario). The range of predicted climate change impacts in the late-2000s on total area compared to the reference scenario are presented in Figure 1 for LFAC countries and in Figure 2 for MFAC countries.

Overall, these graphs indicate that predicted climatic change will worsen crop growing conditions for all crops. The largest climate change impacts are predicted under the A1FI scenario and the smallest impacts are predicted 


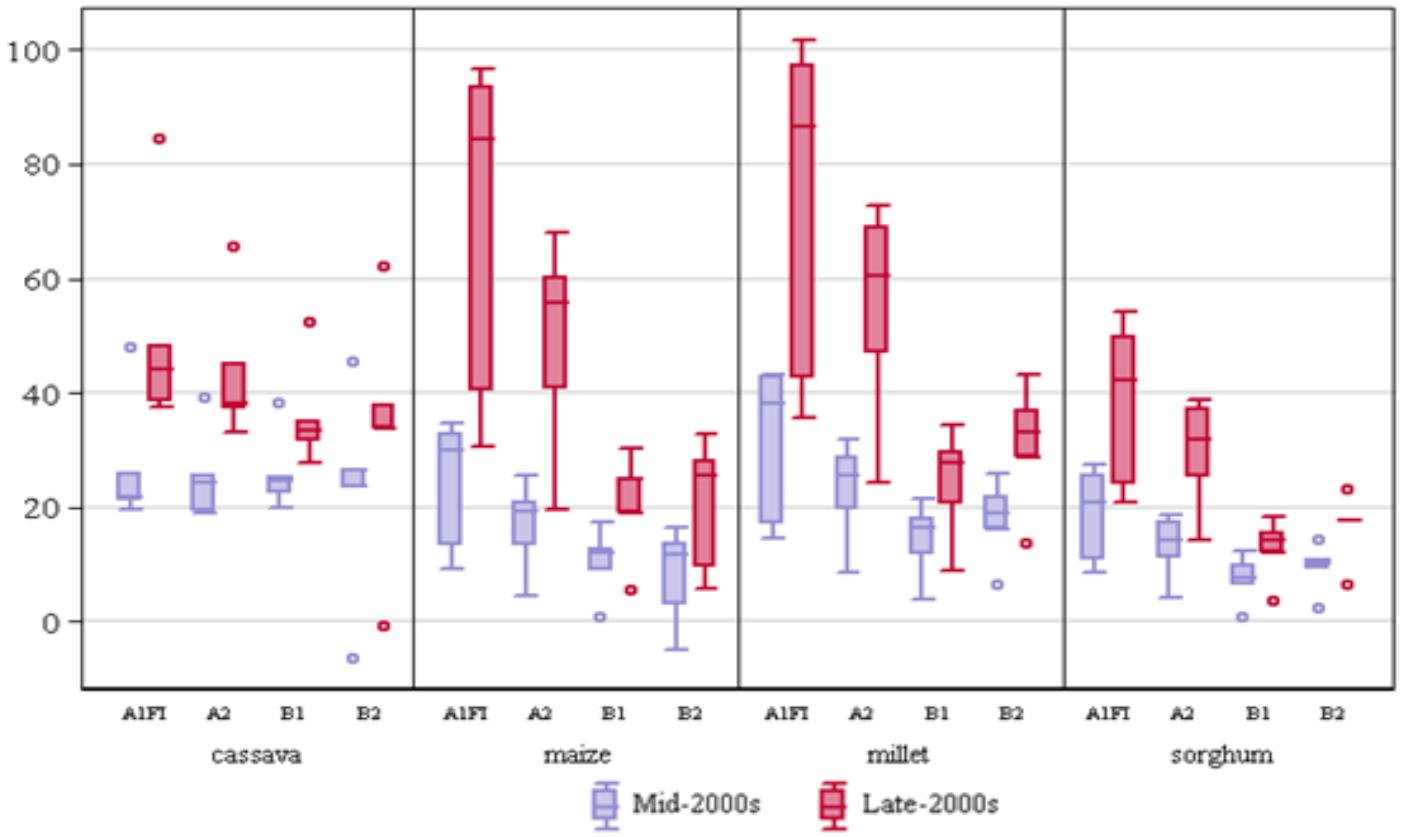

Figure 1. Predicted climate change impact for LFAC countries (in \%) on total area compared to the reference scenario by mid- and late-2000s. Notes: The boxes represent the range of predictions across all AOGCMs between the $25^{\text {th }}$ and $75^{\text {th }}$ percentile for each crop and each scenario. The lines inside the boxes represent the median predictions. The whiskers represent upper and lower adjacent values, unless a prediction is classified as an outsider, which is represented by hollow circles.

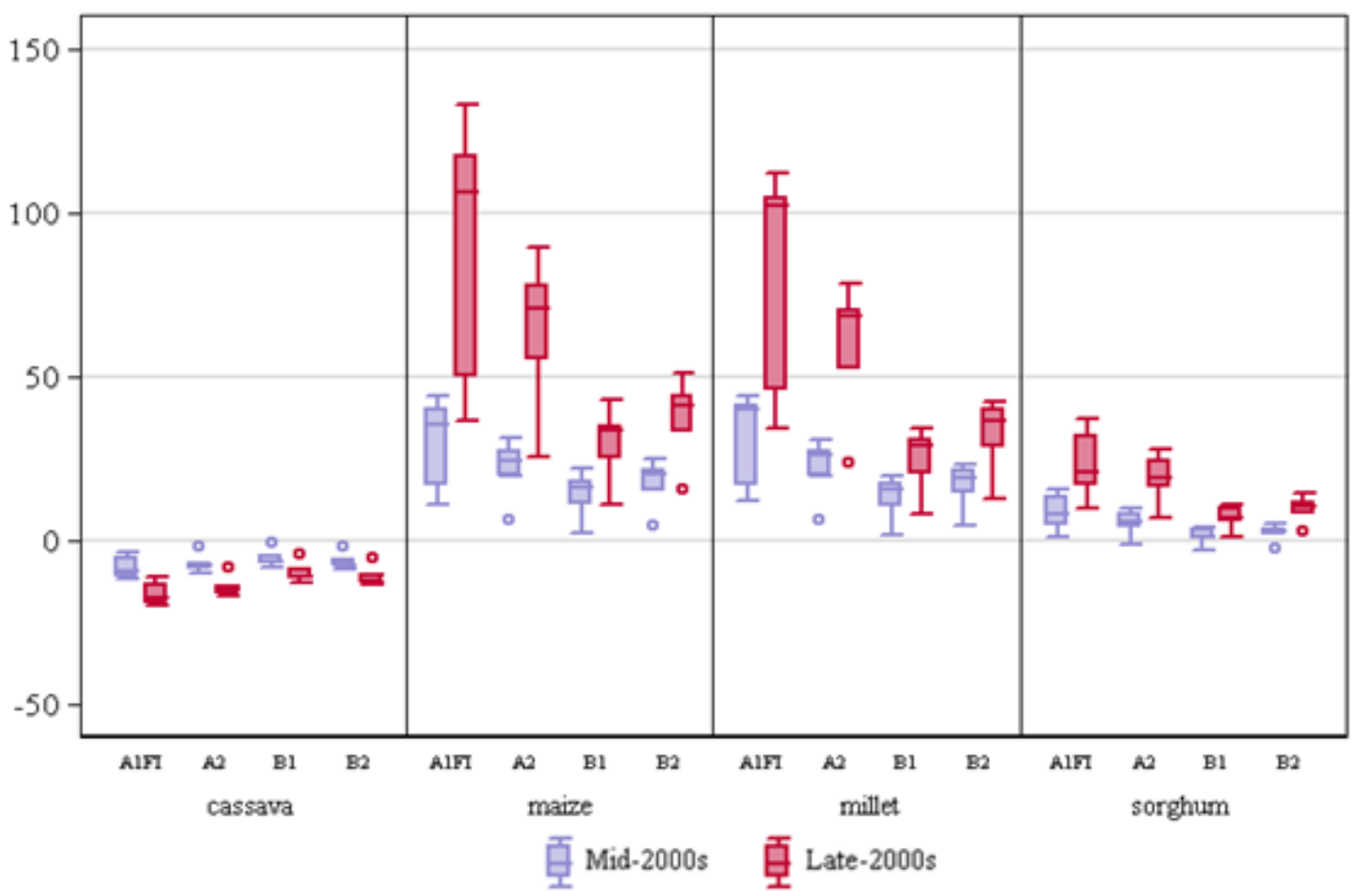

Figure 2. Predicted climate change impact for MFAC countries (in \%) on total area compared to the reference scenario by mid- and late-2000s. Notes: The boxes represent the range of predictions across all AOGCMs between the $25^{\text {th }}$ and $75^{\text {th }}$ percentile for each crop and each scenario. The lines inside the boxes represent the median predictions. The whiskers represent upper and lower adjacent values, unless a prediction is classified as an outsider, which is represented by hollow circles. 
under the B1 scenarios. More specifically, the graphs indicate that cassava area increases from $28 \%$ to $66 \%$ in LFAC countries (with outliers ranging from $-1 \%$ to $+84 \%$ ) and decreases from $4 \%$ to $20 \%$ in MFAC countries by the late-2000s. These predictions indicate that farmers from LFAC countries will increase cassava planting to ensure food production, whereas farmers from MFAC countries will switch to other crops. Areas of the three other crops are expected to increase in both LFAC and MFAC countries to compensate yield losses.

The greatest increase in crop area is predicted for maize in MFAC countries, where area is predicted to be 11 to $133 \%$ higher than under the reference scenario by the late-2000s. In LFAC countries, maize area is predicted to increase from 5 to $100 \%$ by the late-2000s. Areas allocated to millet are predicted to increase from 9 to $102 \%$ in LFAC countries and from 8 to $112 \%$ in MFAC countries by the late-2000s. Climate change causes sorghum area increases from 4 to $54 \%$ in LFAC countries and from 1 to $37 \%$ in MFAC countries in the late-2000s.

\section{Conclusion}

Supply function analyses provide interesting insights about farmers cropping decisions. The regression analyses suggest that, in general, SSA farmers do not adjust crop area allocation in response to crop prices. Alternatively, the analysis reveals that farmers respond to export crop prices. Substitution effects between food crops and export crops are found for sorghum in LFAC countries. Complementarity effects are found between export crops and maize in all countries and between export crops and cassava in LFAC countries.

The results also indicate that farmers' decisions are influenced by weather and climate. Specifically, when temperature and precipitation conditions become more favorable, farmers from MFAC countries increase crop supply and sell excess production. In LFAC countries, however, farmers' decrease their area allocation as production needs are reached more easily and access to market is limited. When temperature and precipitation conditions become less favorable, farmers from MFAC countries decrease crop supply and switch to other crops and activities. Alternatively, farmers from LFAC countries, which have limited alternative options, increase their area allocation to compensate for yield losses.

Considering 20 alternative climate change scenarios, the analysis shows that area cultivated is predicted to increase for all crops during the 21st century. Supply changes are predicted to be the largest under the A1FI scenario, which predicts the largest temperature increases and the largest precipitation changes (which increase or decrease depending on the AOGCM considered). Alternatively, the smallest changes in crop supply are predicted under the B1 scenario, which predicts the smallest increase in temperature and smallest precipitation changes. Compared to a scenario of no climate change, climate change will worsen crop growing conditions for all crops. In LFAC countries, farmers will increase area of all crops to compensate yield losses. In MFAC countries, however, farmers will decrease cassava supply and increase area devoted to other crops, especially maize.

The consideration of alternative scenario shows that impacts are smaller under the B1 scenario, which assumes reduced GHG emissions via, among other things, the introduction of clean and resource-efficient technologies and focusing on global solutions to economic, social and environmental sustainability. These results indicate that global policies will influence the welfare of people living in SSA.

Several limitations to this study should be noted before closing. First, uncertainties from climate modeling and future scenarios of GHG emissions due to incomplete or unknowable knowledge (New and Hulme, 2000) affect the reliability of climate change predictions. Second, parameter and modeling uncertainty affect econometric based projections. Third, regression-based predictions use past responses to weather and climate. Therefore, technological change and crop supply decisions in the future are expected to follow patterns similar to those observed in the past. This assumption represents a limitation for prediction purposes. Modeling potential alternative agricultural responses would involve alternative techniques, which would complement this analysis. Fourth, adaptation methods are not explicitly represented. Instead, the study implicitly assumed that adaption mechanisms adopted by famers in the past will be employed in the future. Fifth, price changes caused by climate change are not considered in the analysis. However, several studies show that price changes caused by climate change have an important impact on production (Reilly et al., 1994, 2007; Reilly, 2011). Estimates from this study could contribute to a CGE analysis that considers price changes induced by climate change. Finally, the study does not account for crop spatial migration outside the predetermined crop zones.

\section{REFERENCES}

Abbas G, Hussain A, Ahmad A, Wajid SA (2005). Water use efficiency of maize as affected by irrigation schedules and nitrogen rates, $\mathrm{J}$. Agric. Soc. Sci. 1(4):339-342.

Adams R, McCarl B, Segerson K, Rosenzweig C, Bryant KJ, Dixon BL, Conner R, Evenson R, Ojima D (1999). The economic effects of climate change on US agriculture, in R. Mendelsohn, Neumann, J. ed., The Impact of Climate Change on the United States Economy. Cambridge University Press, Cambridge, UK.

Adams RM, Fleming RA, Chang CC, McCarl BA, Rosenzweig C (1995). A Reassessment of the Economic Effects of Global Climate Change on U.S. Agriculture, Climatic Change 30:147-167.

Alemu ZG, Oosthuizen K, van Schalkwyk HD (2003). Grain-supply response in Ethiopia: an error-correction approach, Agrekon 42(4).

Amissah-Arthur A (2005). Value of climate forecasts for adjusting farming strategies in sub-Saharan Africa. Geo. J. 62:181-189.

Arellano M, Bond S (1991). Some tests of specification for panel data: Monte Carlo evidence and an application to employment equations. 
Rev. Econ. Stud. 58:277-297.

Askari H, Cummings JT (1977). Estimating agricultural supply response with the Nerlove model: Surv. Int. Econ. Rev. 18(2):257-292.

Badiane O, Delgado C (1995). A 2020 Vision for Food, Agriculture, and the Environment in sub-Saharan Africa, Food, Agriculture, and the Environment Discussion Paper. International Food Policy Research Institute, Washington, DC.

Bates JM, Granger CWJ (1969). The Combination of Forecasts. Oper. Res. Q. 20:451-468.

Ben Mohamed A, Van Duivenbooden N, Abdoussallam S (2002). Impact of climate change on agricultural production in the Sahel-Part 1: Methodological approach and case study for groundnut and cowpea in Niger, Climatic Change 54(3):327-348.

Bhagat LN (1989). Supply Response in Backward Agriculture: An Econometric Analysis of Chotanagpur Region. Concept Publishing company, New Delhi.

Binswanger H, Yang M-C, Bowers A, Mundlak $Y$ (1987). On the determinants of cross-country aggregate agricultural supply, J. Economet. 36(1-2):111-131.

Blanc É (2012). The impact of climate change on crop yields in subSaharan Africa. Am. J. Clim. Change 1(1):1-13.

Bond ME (1983). Agricultural responses to prices in sub-Saharan African countries, Staff Papers-International Monetary Fund 30(4):703-726.

Boserup E (1965). The Conditions of Agricultural Growth: Economics of Agrarian Change under Population Pressure. Allen and Unwin, London.

Boussard J-M, Daviron B, Gérard F, Voituriez T (2005). Food Security and Agricultural Development in Sub-Saharan Africa: Building a Case for More Support. CIRAD.

Braulke M (1982). A note on the Nerlove model of agricultural supply response. Int. Econ. Rev. 23(1):241-244.

Brons J, Ruben R, Toure M, Ouedraogo B (2004). Driving forces for changes in land use, in T. Dietz, R. Ruben and A. Verhagen eds., The impact of climate change on drylands: with a focus on West Africa. Kluwer Academic, Dordrecht.

Collier P (1993). Africa and the study of economics, in R. H. Bates, V. Y. Mudimbe and J. F. O'Barr eds., Africa and the disciplines: the contribution of research in Africa to the social sciences and humanities. The University of Chicago Press.

Collier P, Gunning JW (1999). Explaining African Economic Performance, J. Econ. Literat. 37(1):64-111.

Coyle BT (1993). Modeling Systems of Crop Acreage Demands, J. Agric. Resour. Econ. 18(1):57-69.

Cure JD, Acock B (1986). Crop responses to carbon dioxide doubling: a literature survey. Agric. Forest Meteorol. 38:127-145.

Darwin R, Tsigas M, Lewandrowski, J, Raneses A (1995). World Agriculture and Climate Change: Economic Adaptation. Washington DC, Department of Agriculture. ERS Agric. Econ. Report No AER-P. 709.

de Vries J (1975). Structure and Prospects of the World Coffee Economy. Washington. World Bank Staff Working P. 208.

Demery L, Addison T (1987). The Alleviation of Poverty Under Structural Adjustment. World Bank, Washington, DC.

Diao X, Hazell P, Resnick D, Thurlow J (2006). The role of agriculture in development: implications for Sub-Saharan Africa. International Food Policy Research Institute (IFPRI). DSGD discussion P. 29.

Dixon J, Gulliver A, Gibbon D (2001). Farming Systems and Poverty. Improving farmers' livelihoods in a changing world. Food and Agriculture Organization of the United Nations.

Douya E (2008). Cotton supply response in Cameroon in Developing a Sustainable Economy in Cameroon. CODESRIA, Dakar, Senegal.

Driscoll JC, Kraay AC (1998). Consistent Covariance Matrix Estimation with Spatially Dependent Panel Data. Rev. Econ. Stat. 80:549-560.

Elliott G, Rothenberg TJ, Stock J. H (1996). Efficient Tests for an Autoregressive Unit Root, Econometrica (64):813-836.

FAO (2010). Crops Statistics - Concepts, Definitions and Classifications.

FAO Terrastat (2007). Land resource potential and constraints statistics at country and regional level.

FAOSTAT (2007). FAO Statistical Databases. http://faostat.fao.org.

Fermont AM, van Asten PJA, Tittonell P, van Wijk MT, Giller KE (2009).
Closing the cassava yield gap: An analysis from smallholder farms in East Africa. Field Crops Res. 112(1):24-36.

Flato GM, Boer GJ (2001). Warming asymmetry in climate change simulations. Geophys. Res. Lett. 27:195-198.

Gleditsch NP, Wallensteen P, Eriksson M, Sollenberg M, Strand H (2002). "Armed Conflict 1946-2001: A New Dataset." J. Peace Res. 39(5): 615-637.

Gordon C, Cooper C, Senior CA, Banks H, Gregory JM, Johns T, C, Mitchell JFB, Wood RA (2000). The simulation of SST, sea ice extents and ocean heat transports in a version of the Hadley Centre coupled model without flux adjustments. Clim. Dyn. 16(2-3):147-168.

Gordon HB, O'Farrell SP (1997). Transient climate change in the CSIRO coupled model with dynamic sea ice. Mon. Weather Rev. 125:875-907

Greene W (2000). Econometric Analysis. Prentice-Hall, Upper Saddle River, NJ.

Hattink W, Heerink N, Thijssen G (1998). Supply Response of Cocoa in Ghana: a Farm-level Profit function Analysis. J. Afr. Econ. 7(3):424444.

Heston A, Summers R, Aten B (2006). Penn World Table Version 6.2 (dataset).

Hillocks RJ, Thresh JM, Bellotti A (2001). Cassava: biology, production and utilization. $\mathrm{CABI}$ Publishing.

Huq A, Arshad F (2010). Supply response of Potato in Bengladesh: A vector error correction approach. J. Appl. Sci. 10(11):895-902.

IAC (2004). Realizing the Promise and Potential of African Agriculture. InterAcademy Council.

IPCC (2000). Special Report on Emissions Scenarios. Cambridge University Press.

IPCC (2001). IPCC Third Assessment Report: Climate Change 2001, in D. J. Dokken, M. Noguer, P. van der Linden, C. Johnson J, Pan G.-A D. Studio eds. Cambridge University Press, Cambridge, UK and New York, NY, USA.

Jaeger W (1991). The impact of policy in African agriculture : an empirical investigation. The World Bank. Policy Res. Work. Pap. Ser. P. 640 .

Jones PG, Thornton PK (2003). The potential impacts of climate change on maize production in Africa and Latin America in 2055. Glob. Environ. Change 13:51-59.

Just RE, Zilberman D, Hochman E (1983). Estimation of Multicrop Production Functions. Am. J. Agric. Econ. 65(4):770-780.

Lahiri AK, Roy P (1985). Rainfall and supply-response: A study of rice in India. J. Dev. Econ. 18(2-3):315-334.

Larsson H (1996). Relationships between rainfall and sorghum, millet and sesame in the Kassala Province. Eastern Sudan J. Arid Environ. 32:211-223.

Leaver $\mathrm{R}$ (2004) Measuring the supply response function of tobacco in Zimbabwe. Agrekon 43(1).

Leff B, Ramankutty N, Foley J (2004). Geographic distribution of major crops across the world. Glob. Biogeochem. Cycles P. 18.

Maddison D (2006). The Perception Of And Adaptation To Climate Change In Africa, CEEPA Discussion Paper, Special Series on Climate Change and Agriculture in Africa.

Maunder WJ (1992). Dictionary of global climate change. UCL Press Ltd., London.

McKay AM, Morrissey O, Valliant C (1998). Aggregate export and food crop supply response in Tanzania. CREDIT Project on infrastructural and institutional constraints to export promotion, as part of the DFID Trade and Enterprise Research Program (TERP). CREDIT Res. P. 4.

Mendelsohn R, Nordhaus, WD, Shaw D (1994). The Impact of Global Warming on Agriculture: A Ricardian Analysis. Am. Econ. Rev. 84(4):753-771.

Michaelsen J (1987). Cross-validation in statistical climate forecast models, J. Climate. Appl. Meterorol. 26:1589-1600.

Minot N, Kherallah M, Berry P (2000). Fertilizer market reform and the determinants of fertilizer use in Benin and Malawi. International Food Policy Research Institute (IFPRI). MSSD discussion P. 40.

Mitchell TD (2007). TYN SC 2.0. Tyndall Center for climate change research

Mitchell TD, Carter TR, Jones PD, Hulme M, New M (2003). A comprehensive set of high-resolution grids of monthly climate for Europe and the globe: the observed record (1901-2000) and 16 
scenarios (2001-2100), Working Paper 55. Tyne Centre for Climate Change Research, University of East Anglia, Norwich, UK (for CRU TS 2.02).

Mitchell TD, Jones PD (2005). An improved method of constructing a database of monthly climate observations and associated high resolution grids. Int. J. Climatol. 25:693-712.

Mose LO, Burger K, Kuvyenhoven A (2007). Aggregate supply response to price incentives: the case of smallholder maize production in Kenya, African crop science conference proceedings.

Muchapondwa E (2009). Supply response of Zimbabwean agriculture: 1970-1999. Afr. J. Agric. Resour. Econ. 3(1):28-42.

Nerlove M (1956). Estimates of the Elasticities of Supply of Selected Agricultural Commodities, J. Farm Econ. 38(2):496-509.

Nerlove M (1958). Distributed Lags and Estimation of Long-run Supply and Demand Elasticities: Theoretical Considerations, J. Farm. Econ. 40:301-311.

Nerlove M (1979). The Dynamics of Supply: Retrospect and Prospect, Am. J. Agric. Econ 61(5):874-888.

New M, Hulme M (2000). Representing uncertainty in climate change scenarios: a Monte-Carlo approach Integrated Assessment 1:203213.

Ngambeki DS, Idachaba FS (1985). Supply response of upland rice in ogun state of nigeria: a producer panel approach. J. Agric. Econ. 36(2):239-249.

Nhemachena C, Hassan R (2007). Micro-Level Analysis of Farmers Adaption to climate change in Southern Africa. IFPRI Discussion P. 00714

Nkang NM, Ndifon HM, Edet EO (2007). Maize Supply Response to Changes in Real Prices in Nigeria: A Vector Error Correction Approach, Agric. J. 2(3):419-425

NRC (2008). Emerging Technologies to Benefit Farmers in SubSaharan Africa and South Asia. The National Academies Press, National Research Council, Committee on a Study of Technologies to Benefit Farmers in Africa and South Asia, Washington, DC.

Odjugo PAO (2008). The impact of tillage systems on soil microclimate, growth and yield of cassava (Manihot utilisima) in Midwestern Nigeria. Afr. J. Agric. Res. 3(3):225-233.

Ogbu OM, Gbetibouo M (1989). Agricultural Supply Response in SubSaharan Africa: A Critical Review of the Literature. Afr. Dev. Rev. pp. 83-99.

Olayemi JK, Oni S (1972). Asymmetry in price response: a case study of Western Nigerian cocoa farmers. Nig. J. Econ. Social Stud. 14(3):47-55

Pandey RK, Maranville JW, Admou A (2000). Deficit irrigation and nitrogen effects on maize in a Sahelian environment: I. Grain yield and yield components. Agric. Water Manag. 46(1):1-13.

Parikh A (1979). Estimation of supply functions for coffee. Appl. Econ. 11(1):43-54

Patt A, Gwata C (2002). Effective Seasonal Climate Forecast Applications: Examining Constraints for subsistence farmers in Zimbabwe. Glob. Environ. Change 12:185-195.

Pesaran MH (2004). General diagnostic tests for cross section dependence in panels, Cambridge Working Papers in Economics. University of Cambridge, Faculty of Economics.

Rahji MAY, llemobayo OO, Fakayode SB (2008). Rice supply response in Nigeria: an application of the Nerlovian Adjustment model, Agric. J. 3(3):229-234.

Recha CW, Shisanya CA, Makokha GL, Krnuthia RN (2008) Perception and Use of Climate Forecast Information Amongst Smallholder Farmers in Semi-Arid Kenya. Asian J. Appl. Sci. 1(2:123-135.

Reilly J (2011). Chapter 13: The Role of Growth and Trade in Agricultural Adaptation to Environmental Change, in Dinar and Mendelsohn eds., Handbook on Climate Change and Agriculture. Edward Elgar Publishing (forthcoming).

Reilly J, Hohmann N, Kane S (1994). Climate change and agricultural trade. Glob. Environ. Change 4:24-36.

Reilly J, Paltsev S, Felzer B, Wang, X, Kicklighter D, Melillo J, Prinn R, Sarofim M, Sokolov A, Wang C (2007). Global economic effects of changes in crops, pasture, and forests due to changing climate, carbon dioxide, and ozone, Energy Policy 35:5370-5383.
Rockström J, Folke C, Gordon L, Hatibu, N., Jewitt, G., Penning de Vries F, Rwehumbiza F, Sally H, Savenije H, Schulze R (2004). A watershed approach to upgrade rainfed agriculture in water scarce regions through Water System Innovations: an integrated research initiative on water for food and rural livelihoods in balance with ecosystem functions, Physics and Chemistry of the Earth 29:11091118.

Roeckner E, Oberhuber JM, Bacher A, Christoph M, Kirchner I (1996). ENSO variability and atmospheric response in a global coupled atmosphere-ocean GCM. Clim. Dyn. 12:737-754.

Sangwan SS (1985). Dynamics of cropping pattern in Haryana: a supply response analysis. Dev. Econ. XXIII(2).

Savadatti PM (2007). An Econometric Analysis of Demand and Supply Response of Pulses in India, Karnataka J. Agric. Sci. 20(3):545-550.

Schlenker W, Lobell DB (2010). Robust negative impacts of climate change on African. Agric. Environ. Res. Lett. 5:1-8.

Smit B, Skinner MW (2002). Adaptation options in agriculture to climate change: Typology, Mitigation Adapt. Strategies Glob. Change 7:85114.

Subervie J (2008). The Variable Response of Agricultural Supply to World Price Instability in Developing Countries, J. Agric, Econ. 59(1):72-92.

Thiele R (2000). Estimating the Aggregate Agricultural Supply Response: A Survey of Techniques and Results for Developing Countries. Kiel, Germany. Kiel Working P. 1016.

Thiele R (2003). Price Incentives, Non-Price Factors, and Agricultural Production in Sub-Saharan Africa: A Cointegration Analysis, Contributed paper selected for presentation at the 25th International Conference of Agricultural Economists, Durban, South Africa.

Thornton PK, Jones PG, Alagarswamy G, Andresen J (2009) Spatial variation of crop yield response to climate change in East Africa, Global Environmental Change 19(1):54-65.

Timmermann A (2006). Forecast combinations, in G. Elliott, C. W. J. Granger and A. Timmermann eds., Handbook of economic forecasting, 1. North Holland, Amsterdam.

Udry C (1999). Efficiency and market structure: Testing for Profit Maximization in African Agriculture, in G. Ranis and L. K. Raut eds. Trade, growth and development: Essays in honor of Professor T. N. Srinivasan. Elsevier Science

Upton M (1987). African farm management. Cambridge University Press, Cambridge.

Van Duivenbooden N, Abdoussallam S, Ben Mohamed A (2002). Impact of climate change on agricultural production in the Sahel-Part 2: Methodological approach and case study for millet in Niger Climatic Change 54(3), 349-368.

Washington WM, Weatherly JW, Meehl GA, Semtner AJ, Bettge TW, Craig AP, Strand, WG., Arblaster JM, Wayland VB, James R, Zhang $Y$ (2000). Parallel climate model (PCM) control and transient simulations. Clim. Dyn. 16:755-774.

Weite Z, Xiong L, Kaimian L, Jie H, Yinong T, Jun L, Quohui F (1998). Cassava agronomy research in China, in R. H. Howeler ed., Cassava Breeding, Agronomy and Farmer Participatory in Asia. Proceedings of the 5th Regional Workshop, held in Danzhou, Hainan, China. Nov 3-8, 1996.

Westerlund J (2007). Testing for Error Correction in Panel Data. Oxford Bull. Econ. Stat. 69(6):709-748.

Wolman MG, Fournier FGA (1987). Agricultural practices leading to land transformation: Introduction, in M. G. Wolman and F. G. A Fournier eds., Land transformation in agriculture. John Wiley \& Sons, Chichester, UK.

Yamoah CF, Varvel GE, Francis CA, Waltman WJ (1998). Weather and management impact on crop yield variability in rotations. J. Prod Agric. 11(2):219-225.

Zaal F, Dietz T, Brons J, van der Geest K, Ofori-Sarpong E (2004). Sahelian Livelihoods on the Rebound, in A. J. Dietz, R. Ruben and A. Verhagen eds., The Impact of Climate Change on Drylands, with a Focus on West Africa. Kluwer Academic Publishers, Dordrecht, Boston, London. 